and arrangements were made on a semi-commercial scale to purify the helium by liquefying the methane and other gases present. About the same time, the Bureau of Mines of the United States began similar experiments, using the natural gases of Texas, which are rich in helium. At the end of the War, millions of cubic feet of helium were separated by liquefaction methods, and the cost was found to be sufficiently low to use it in airships in place of hydrogen. The U.S. airships, the Shenandoah and the Akron, were both filled with helium to avoid the dangers of fire. Apart from this and other industrial uses, helium is of great importance in the liquid form for attaining temperatures not far removed from absolute zero. A number of cryogenic laboratories employing liquid helium are in active operation in Europe, Canada and the United States, for the study of the properties of matter near the absolute zero of temperatures.

\section{Congress of Anthropological and Ethnological Sciences}

A PReliminary programme of the first session of the International Congress of Anthropological and Ethnological Sciences to meet in London under the presidency of the Earl of Onslow from July 30 until August 4 next is now available. The headquarters will be at University College, Gower Street, W.C.2. The inaugural meeting will take place in the Great Hall of the College on July 30 at 3 p.m., when H.R.H. the Duke of York will receive the delegates and declare the Congress open, and Lord Onslow will deliver his presidential address. On the same day at 10 p.m. H.M. Government will hold a reception of the members of the Congress at Lancaster House, St. James's, S.W. The business of the Congress will be conducted in general and sectional meetings. At the first of the general meetings, which will be held on July 31 at 8.30 p.m., Sir Aurel Stein will deliver the Huxley Memorial Lecture of the Royal Anthropological Institute and will receive the Institute's Huxley Memorial Medal for 1934. At subsequent general meetings in the evenings of the following days, the Congress will be addressed by Dr. R. R. Marett, Prof. T. C. Hodson, and Prof. J. B. S. Haldane, each of whom will deal with some one aspect of present tendencies in anthropological studies. Communications addressed to the Congress by its members will be submitted to meetings of the sections, of which there will be eight, each one dealing with a major division of the studies with which the Congress is concerned.

So far as it is possible to judge from this preliminary outline, the proceedings of the sections will be of the greatest interest. In each section topics of inquiry are suggested, although members are not thereby necessarily precluded from submitting communications on other matters. In the Anatomical and Physical Section, which will meet under Prof. Elliot Smith, for example, the central theme will be man's place among the primates. In most sections, however, the range is sufficiently wide to cover all points which members are likely to have time or desire to discuss. Joint meetings between two or more sections occupy a prominent place in the programme. The Section of Ethnography, which, naturally, is expected to have the heaviest list of communications, will meet in three divisions, General Ethnography under Dr. A. C. Haddon, African Ethnography under the Rev. E. W. Smith and American Ethnography under Capt. T. A. Joyce. The last named sub-section has been specially arranged with the view of welcoming American workers on their way to attend the International Congress of Americanists to be held later at Seville. It will take as its central theme of discussion the interrelation of pre-Spanish American culture centres and their possible connexion with extra-American influences, affording, it is hoped, a welcome opportunity for placing on record the results of the most recent developments in research. In the African Section current problems impinging on questions of administration and the future development of the African will be kept well in view. The subscription to the Congress is: members $£ 1$, associates $10 \mathrm{~s}$. Further particulars may be obtained from the Congress Secretaries, c/o the Royal Anthropological Institute, 52 Upper Bedford Place, London, W.C.2.

\section{Japanese Trade Competition}

JAPANESE competition in the world's markets is more than a new and noteworthy fact. Discussing the matter in a recent issue of the Industrial Chemist, Sir Harry McGowan, chairman and managing director of Imperial Chemical Industries, Ltd., shows that by no means the whole story involves the long hours of work and the low standard of living of the Japanese worker; contributory aids to Japan's advance are her realisation that, in times of depression, price is more important than quality, and her study of the needs of individual markets. "Her manufacturers . . . give each customer what he wants at the time and place that it is wanted, and patterned, designed, and packed in a manner to please his particular fancy.... They quote in his own language, and express units of quantity and price in the measurements of his country." Japan needs to sell goods abroad to maintain some equilibrium in her trade balance, to support her rapidly growing population, and to pay for her increasing armaments. She has the advantage of a considerably depreciated currency; a newcomer into the industrial arena, she has bought the most up-to-date machinery and adopted the most suitable methods, and she has organised her industries in large-scale units. She has evolved a system of industrial and governmental co-operation in the conduct of export campaigns. Sir Harry McGowan counsels us to take prompt and vigorous steps to put ourselves so far as possible on a competitive basis. We will not, and indeed cannot, depress the standard of living of our workpeople, but we can reap the advantages of industrial organisation and the effective planning of export trade. The time has come for closer personal contact between British and Japanese industrialists, and for discussion which will lead to a tempering of healthy competition with reasonable co-operation. 